\title{
Erythropoietin exposure of isolated pancreatic islets accelerates their revascularization after transplantation
}

\author{
Maximilian M. Menger ${ }^{1,2} \cdot$ Lisa Nalbach$^{1} \cdot$ Leticia P. Roma $^{3} \cdot$ Matthias W. Laschke $^{1} \cdot$ Michael D. Menger $^{1}$. \\ Emmanuel Ampofo' ${ }^{1}$
}

Received: 16 April 2021 / Accepted: 6 June 2021 / Published online: 12 July 2021

(c) The Author(s) 2021

\begin{abstract}
Aims The exposure of isolated pancreatic islets to pro-angiogenic factors prior to their transplantation represents a promising strategy to accelerate the revascularization of the grafts. It has been shown that erythropoietin (EPO), a glycoprotein regulating erythropoiesis, also induces angiogenesis. Therefore, we hypothesized that EPO exposure of isolated islets improves their posttransplant revascularization.

Methods Flow cytometric, immunohistochemical and quantitative real-time (qRT)-PCR analyses were performed to study the effect of EPO on the viability, cellular composition and gene expression of isolated islets. Moreover, islets expressing a mitochondrial or cytosolic $\mathrm{H}_{2} \mathrm{O}_{2}$ sensor were used to determine reactive oxygen species (ROS) levels. The dorsal skinfold chamber model in combination with intravital fluorescence microscopy was used to analyze the revascularization of transplanted islets.

Results We found that the exposure of isolated islets to EPO ( 3 units $/ \mathrm{mL}$ ) for $24 \mathrm{~h}$ does not affect the viability and the production of ROS when compared to vehicle-treated and freshly isolated islets. However, the exposure of islets to EPO increased the number of CD31-positive cells and enhanced the gene expression of insulin and vascular endothelial growth factor (VEGF)-A. The revascularization of the EPO-cultivated islets was accelerated within the initial phase after transplantation when compared to both controls.

Conclusion These findings indicate that the exposure of isolated islets to EPO may be a promising approach to improve clinical islet transplantation.
\end{abstract}

Keywords Erythropoietin $\cdot$ Islets $\cdot$ Transplantation $\cdot$ Revascularization $\cdot$ Diabetes $\cdot$ Angiogenesis

Managed by Massimo Federici.

Maximilian M. Menger, Lisa Nalbach are contributed equally to this work.

Emmanuel Ampofo

emmanuel.ampofo@uks.eu

1 Institute for Clinical and Experimental Surgery, Saarland University, 66421 Homburg, Saar, Germany

2 Department of Trauma and Reconstructive Surgery, Faculty of Medicine, BG Hospital Tuebingen, Eberhard-Karls-University Tuebingen, Tuebingen, Germany

3 Biophysics Department, Center for Human and Molecular Biology, Saarland University, 66421 Homburg, Saar, Germany

\section{Introduction}

Pancreatic islet transplantation is a promising therapeutic strategy for the reestablishment of glucose homeostasis in patients suffering from type 1 diabetes [1]. This minimally invasive approach has the advantage to reduce the surgical trauma associated with whole organ pancreas transplantation and to prevent complications induced by the exocrine pancreatic tissue. However, insufficient graft revascularization leads to apoptotic and necrotic islet cell death during the initial posttransplant period and, thus, represents a major drawback of islet transplantation [2]. Accordingly, the improvement of graft revascularization is of major clinical interest.

Several studies have reported that the glycoprotein erythropoietin (EPO) is capable of inducing the formation of new blood vessels [3, 4]. This is mediated by the binding of EPO to its corresponding receptor (EPOR) on 
endothelial cells, which activates pro-angiogenic signaling pathways $[5,6]$. Pancreatic $\beta$-cells also express EPOR and the cultivation of islets with EPO protects $\beta$-cells from cytokine-induced apoptosis [7]. Moreover, in vivo injection of EPO reduces $\beta$-cell damage by promoting antioxidative processes $[8,9]$. We have previously shown that pretreatment of mice with EPO significantly accelerates the revascularization of transplanted islets [10]. However, an adequate pretreatment of patients with EPO is hard to achieve under clinical conditions, because there is little time between receiving the appropriate donor pancreas and the islet transplantation itself. Hence, the treatment of the isolated islets with EPO prior to transplantation may be an alternative approach to improve their revascularization.

To test this hypothesis, we cultivated mouse isolated islets with EPO $(\mathrm{CI}+\mathrm{EPO})$ or vehicle $(\mathrm{CI}+$ vehicle $)$ for $24 \mathrm{~h}$ and assessed their viability, reactive oxygen species (ROS) levels, cellular composition and gene expression. Moreover, we used freshly isolated mouse islets (FI) as an additional control. In vivo, $\mathrm{CI}+\mathrm{EPO}, \mathrm{CI}+$ vehicle and FI were transplanted into dorsal skinfold chambers of syngeneic recipient mice to analyze the islets' revascularization by means of intravital fluorescence microscopy and immunohistochemistry. Here, we show for the first time that EPO cultivation accelerates the revascularization of transplanted islets during the initial post-transplantation phase.

\section{Material and methods}

\section{Chemical and biological reagents}

Collagenase NB 4G was purchased from SERVA Elektrophoresis GmbH (Heidelberg, Germany). Neutral red, fluorescein isothiocyanate (FITC)-dextran 150,000, rhodamine 6G and Hoechst 33,342 were purchased from SigmaAldrich (Taufkirchen, Germany). Mayer's hemalaun was purchased from Merck (Darmstadt, Germany), ketamine (Ursotamin ${ }^{\circledR}$ ) from Serumwerke Bernburg (Bernburg, Germany) and xylazine (Rompun ${ }^{\circledR}$ ) from Bayer (Leverkusen, Germany). HepatoQuick ${ }^{\circledR}$ and EPO- $\beta$ (recombinant human EPO, NeoRecormon ${ }^{\circledR}$ ) were purchased from Roche (Basel, Switzerland). The antibody anti-EPOR (BS1424R) was purchased from Fisher Scientific (Hampton, USA). The antibody anti-CD31 (DIA310) was purchased from Dianova (Germany). The antibody anti-green fluorescent protein (GFP) was purchased from Rockland Immunochemical Inc. (Limerick, USA) and the antibodies anti-insulin as well as 3-amino-9-ethylcarbazole (AEC Substrate System) from Abcam (Cambridge, UK).

\section{Animals}

Twelve- to 24-week-old transgenic FVB/N-TgN (Tie2/ GFP) 287 Sato mice (Institute for Clinical \& Experimental Surgery, Homburg/Saar, Germany) with a body weight of 25-30 g were used as donors for islet isolation. These mice express the reporter gene GFP under the transcriptional control of the endothelial Tie2 promotor [11]. Eight to 10-weekold FVB/N wild-type mice with a body weight of $22-27 \mathrm{~g}$ served as recipients for islet transplantation. Transgenic C57BL/6 mice expressing the $\mathrm{H}_{2} \mathrm{O}_{2}$ sensor roGFP2-Orp1 in the cytosol (roGFP2-Orp1) or in the mitochondria (mitoroGFP2-Orp1) were used for intra-islet redox measurements. This mice have been previously reported in detail [12]. All experiments were performed according to the German legislation on protection of animals and the National Institutes of Health (NIH) Guide for the Care and Use of Laboratory Animals (Institute of Laboratory Animal Resources, National Research Council, Washington DC, USA). The experiments were approved by the local governmental animal protection committee (permission number: 58/2015).

\section{Isolation and cultivation of pancreatic islets}

Mice were anesthetized by intraperitoneal (i.p.) injection of ketamine $(80 \mathrm{mg} / \mathrm{kg}$ body weight) and xylazine $(12 \mathrm{mg} / \mathrm{kg}$ body weight). Following cervical dislocation and midline laparotomy, the pancreatic duct was injected with $1 \mathrm{mg} / \mathrm{mL}$ collagenase NB 4G containing $25 \mu \mathrm{L} / \mathrm{mL}$ neutral red solution and pancreatic islets were isolated as described previously in detail [13]. Isolated islets were then cultivated in Dulbecco's Modified Eagle's Medium (DMEM) containing 3 units/mL EPO (CI + EPO) or equivalent volume of saline $\left(\mathrm{CI}+\right.$ vehicle) for $24 \mathrm{~h}$ at $37^{\circ} \mathrm{C}$ and $5 \% \mathrm{CO}_{2}$.

\section{NAD(P)H measurement}

Twenty-five islets per well of a 96-well plate were exposed 3 units $/ \mathrm{mL}$ EPO (CI + EPO) or equivalent volume of saline $(\mathrm{CI}+$ vehicle) for $24 \mathrm{~h}$. Thereafter, the NAD(P)H levels of $\mathrm{CI}+\mathrm{EPO}, \mathrm{CI}+$ vehicle and FI were determined, using the CLARIOstar Microplate Reader (BMG LABTECH, Ortenberg, Germany). NAD(P)H was detected in islets after excitation at $340 \mathrm{~nm}$.

\section{Quantitative real time (qRT)-PCR}

Total RNA was isolated by QIAzol lysis reagent and cDNA was synthesized from $1 \mu \mathrm{g}$ of total RNA according to the manufacturer's instructions of QuantiNova Reverse Transcription Kit (Qiagen). ORA qPCR Green ROX L Mix 
(highQu) was used for qRT-PCR. $\beta$-Actin served as internal control for mRNA detection. The data analysis was performed by the MiniOpticon Real-Time PCR System (Bio-Rad).

Forward and reverse primers were used at a concentration of $700 \mathrm{nM}$ solved in RNase/DNase-free $\mathrm{H}_{2} \mathrm{O}$. Primer sequences for qPCR were as follows: $\beta$-Actin forward $5^{\prime}$ CCTAGGCACCAGGGTGTGAT-3', reverse 5'-TCTCCA TGTCGTCCCAGTTG-3'; Insulin forward 5'-GGGGAG CGTGGCTTCTTCTA-3', reverse 5'-GGGGACAGAATT CAGTGGCA-3'; and VEGF-A forward 5'- GCTGTACCT CCACCATGCCAAG-3', reverse 5'-CGCACTCCAGGG CTTCATCG-3'.

\section{Neutral red and trypan blue staining}

$\mathrm{CI}+\mathrm{EPO}, \mathrm{CI}+$ vehicle and FI were washed in PBS and incubated for $2 \mathrm{~min}$ at room temperature with neutral red $(1: 100)$ or trypan blue $(1: 100)$. Subsequently, the islets were washed again with phosphate buffer saline (PBS) and cellular stainings were visualized by bright field images using a $20 \times$ objective of a BX60 microscope (Olympus, Hamburg, Germany).

\section{Dorsal skinfold chamber}

The revascularization of transplanted islets was analyzed by using the dorsal skinfold chamber model. The chamber was prepared and implanted as described previously in detail [14]. Briefly, mice were anesthetized by i.p. injection of ketamine ( $80 \mathrm{mg} / \mathrm{kg}$ body weight) and xylazine (12 mg/ $\mathrm{kg}$ body weight). Thereafter, two symmetrical titanium frames were implanted on the extended dorsal skinfold of the animals. In a circular area of $15 \mathrm{~mm}$, skin, subcutis, striated muscle and both retractor muscles were completely removed. The remaining layers, consisting of striated muscle, subcutis and skin, were sealed by a removable cover glass, providing direct microscopic access to the microcirculation of the chamber. After the procedure, the tissue was allowed to recover from surgical trauma for $72 \mathrm{~h}$.

For the transplantation of pancreatic islets, mice were anesthetized, the cover glass was removed and the chamber was washed twice with saline. Then, 6 to 8 isolated islets were transplanted onto the striated muscle tissue. After transplantation, the chamber was sealed again with a new cover glass.

\section{Intravital fluorescence microscopy}

A plexiglas stage was used for the fixation of the anesthetized mice. The animals received a retrobulbary, intravenous injection of $0.05 \mathrm{~mL} \mathrm{5 \%} \mathrm{FITC-dextran} \mathrm{for} \mathrm{contrast} \mathrm{enhance-}$ ment of blood plasma. Moreover, $0.05 \mathrm{~mL} 2 \%$ rhodamine $6 \mathrm{G}$, which accumulates in endocrine but not in striated muscle tissue by extravasation from fenestrated endothelium, was intravenously given for the visualization of endocrine tissue revascularization [15]. Then, the dorsal skinfold chamber was positioned under a Zeiss microscope (Zeiss, Oberkochen, Germany) with a $100 \mathrm{~W}$ mercury lamp attached to a blue (excitation wavelength: $450-490 \mathrm{~nm} / \mathrm{emission}$ wavelength: $>515 \mathrm{~nm}$ ) and a green $(530-560 \mathrm{~nm} />585 \mathrm{~nm})$ filter block. The microscopic images were recorded for offline evaluation.

Quantitative analysis of the microscopic images was performed by the computer-assisted image analysis system CapImage (Zeintl, Heidelberg, Germany) and included the determination of the grafts' initial size $\left(\mathrm{mm}^{2}\right)$, revascularized area $\left(\mathrm{mm}^{2}\right)$, functional capillary density $\left(\mathrm{cm} / \mathrm{cm}^{2}\right)$ and endocrine revascularization as previously described [16, 17]. We further measured microhemodynamic parameters, i.e., the diameter $(\mu \mathrm{m})$ and centerline red blood cell (RBC) velocity $(\mu \mathrm{m} / \mathrm{s})$, of individual microvessels within the grafts [16, 17]. Moreover, we assessed the take rate in \% (the fraction of engrafted islets on day 14 in relation to the number of transplanted islets).

\section{Experimental protocol}

Pancreatic islets were isolated from GFP-positive FVB/N donor mice. A total number of $18 \mathrm{FVB} / \mathrm{N}$ wild-type mice were equipped with dorsal skinfold chambers. The mice were randomly assigned to three experimental groups of six animals each. $\mathrm{CI}+\mathrm{EPO}, \mathrm{CI}+$ vehicle as well as FI were transplanted into dorsal skinfold chambers of recipient mice. Repetitive intravital fluorescence microscopy was performed on days $0,3,6,10$ and 14 after islet transplantation. Subsequently, the islet-containing chamber tissue was excised for further histological and immunohistochemical analyses.

\section{Immunohistochemistry}

For the ex vivo experiments, islets from three mice were isolated and pooled. Five islets were transferred into a well of a 96-well plate and exposed to vehicle (CI + vehicle) or $\mathrm{EPO}(\mathrm{CI}+\mathrm{EPO})$ for $24 \mathrm{~h}$ ( $n=9$ wells each). Thereafter, $\mathrm{CI}+$ vehicle, $\mathrm{CI}+\mathrm{EPO}$ and $\mathrm{FI}$ were embedded in a mixture of $100 \mu \mathrm{L}$ HepatoQuick ${ }^{\circledR}, 50 \mu \mathrm{L}$ human citrate plasma and $10 \mu \mathrm{L}$ of $10 \% \mathrm{CaCl}_{2}$. The resulting clots were fixed for $24 \mathrm{~h}$ in $4 \%$ formalin. The formalin-fixed specimens were then embedded in paraffin and $3-\mu$ m-thick sections were cut. 
The sections were stained with an anti-insulin antibody (1:100), an anti-CD31 antibody (1:200) as well as Hoechst 33342 to detect the cell nuclei. The number of insulin and CD31-positive cells in \% of all islet cells (5 islets per clot) were analyzed by means of fluorescence microscopy (BX60F; Olympus, Hamburg, Germany). To detect EPOR, the sections were stained with hematoxylin and an antiEPOR antibody (1:200).

For the analyses of transplanted islets, we generated immunohistological sections from 5 mice containing at least 3 transplanted islets per section. The sections were stained with an anti-insulin antibody (1:100), an anti-CD31 antibody (1:200), an anti-GFP antibody (1:200) as well as Hoechst 33342 to detect the cell nuclei. The number of insulin- and CD31-positive cells in \% of all islet cells and the number of GFP/CD31-positive cells in \% of all CD31positive cells from three sections per mouse were analyzed by means of fluorescence microscopy (BX60F; Olympus, Hamburg, Germany).

\section{Data and statistical analysis}

After testing the data for normal distribution and equal variance, differences between multiple groups were assessed by one-way ANOVA followed by the Tukey post hoc test including the correction of the $\alpha$-error according to Bonferroni probabilities. Statistics were performed by GraphPad Prism (version 8). All values are expressed as scatter plots with median and $95 \%$ confidence interval. Statistical significance was accepted for $P<0.05$.

\section{Figure 1}

a

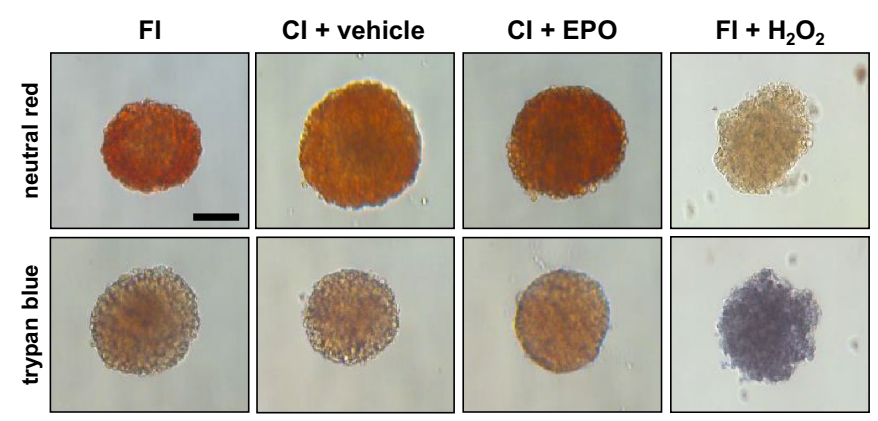

C
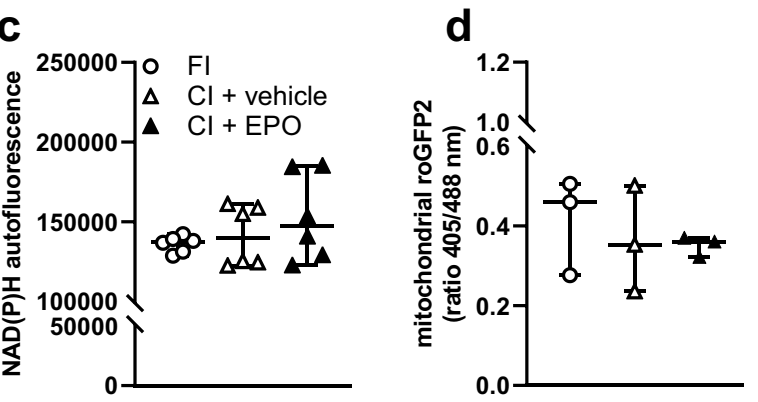

b

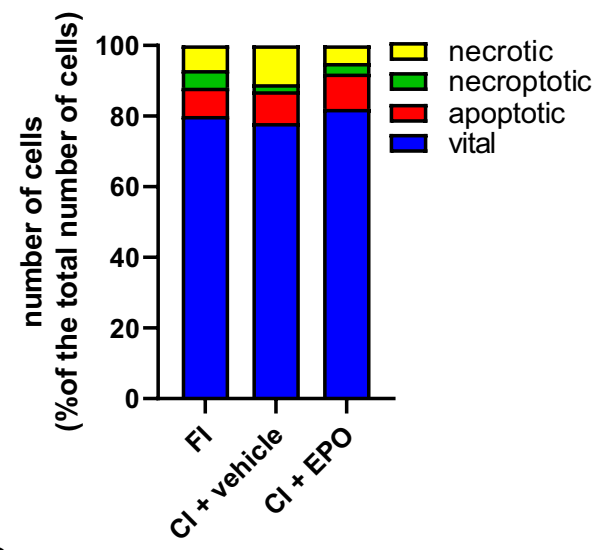

e

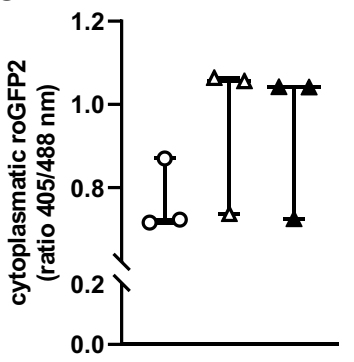

Fig. 1 Effect of EPO cultivation on islet viability. a Neutral red and trypan blue stainings of freshly isolated islets (FI), vehicle-cultivated islets $(\mathrm{CI}+$ vehicle) and $\mathrm{EPO}$-cultivated islets $(\mathrm{CI}+\mathrm{EPO})$. FI incubated for $24 \mathrm{~h}$ with $0.2 \% \mathrm{H}_{2} \mathrm{O}_{2}$ served as control. Scale bar: $70 \mu \mathrm{m}$. b Quantitative analysis of propidium iodide / annexin V-stained cells from FI, CI+ vehicle and CI+EPO subdivided in necrotic, necroptotic, apoptotic and vital cells in $\%$ of the total number of cells $(n=6$ each). c Quantitative analysis of the $\mathrm{NAD}(\mathrm{P}) \mathrm{H}$ levels within FI, $\mathrm{CI}+$ vehicle, and CI + EPO $(\mathrm{n}=6$ each $)$. Data are shown as scatter blots with median and 95\% confidence interval. d and e Quantitative analysis of the ratio of the mitochondrial ROS sensor $\mathbf{e}$ and the cytosolic ROS sensor $\mathbf{f}(n=3$ each). Data are shown as scatter blots with median and $95 \%$ confidence interval 


\section{Results}

\section{Effect of EPO cultivation on isolated islet viability}

In a first set of experiments, we performed neutral red- and trypan blue stainings to assess the effect of $24 \mathrm{~h}$ EPO cultivation on the viability of isolated islets. We did not detect any differences between FI, CI + vehicle and CI + EPO (Fig. 1a). We additionally performed flow cytometric analyses of Annexin V / propidium iodide-stained cells and NAD $(\mathrm{P}) \mathrm{H}$ measurements (Fig. $1 \mathrm{~b}$ and c). The results of these detailed viability assays confirmed that the cultivation of islets with EPO does not exert cytotoxic effects.
Cultivation of islets may induce hypoxic stress, which leads to elevated intracellular ROS levels $[18,19]$. To assess whether EPO affects intracellular ROS levels of cultivated islets, we used islets from transgenic mice expressing mitochondrial or cytosolic $\mathrm{H}_{2} \mathrm{O}_{2}$ biosensors [12]. These biosensors change their fluorescence emission according to the ratio of oxidized $(405 \mathrm{~nm})$ to reduced roGFP2 $(488 \mathrm{~nm})$ depending on $\mathrm{H}_{2} \mathrm{O}_{2}$ levels. The quantitative analysis of the $405 \mathrm{~nm} / 488 \mathrm{~nm}$ ratio clearly demonstrated that EPO cultivation affects neither cytosolic nor mitochondrial $\mathrm{H}_{2} \mathrm{O}_{2}$ levels (Fig. 1d and e). a

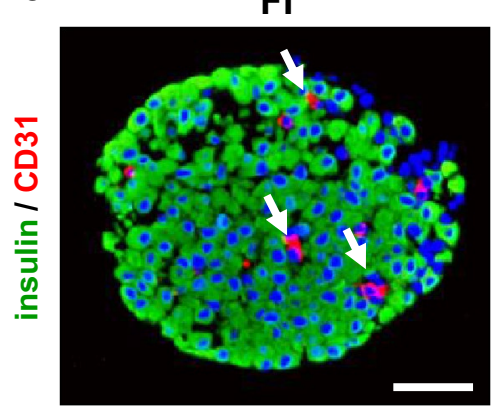

$\mathrm{Cl}+$ vehicle

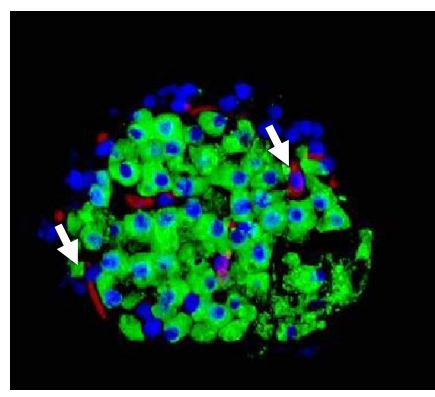

d
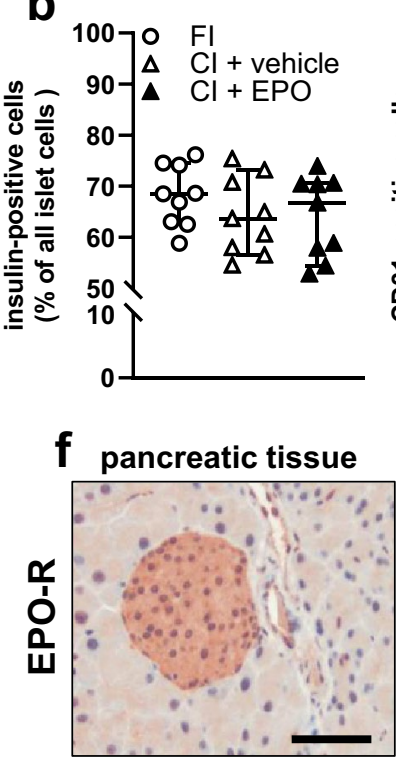

C

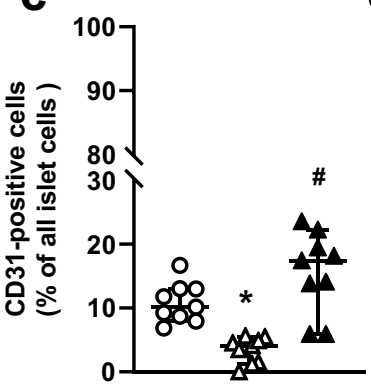

FI

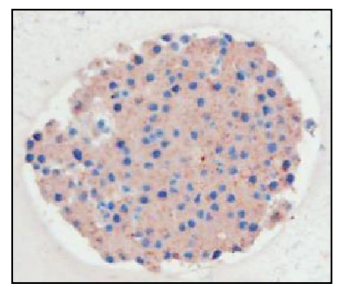

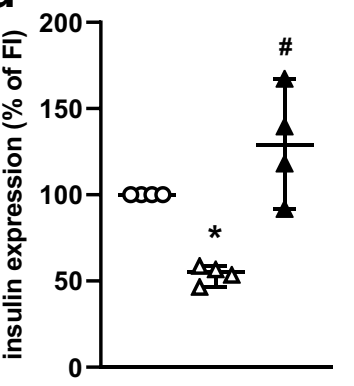

$\mathrm{Cl}+$ vehicle

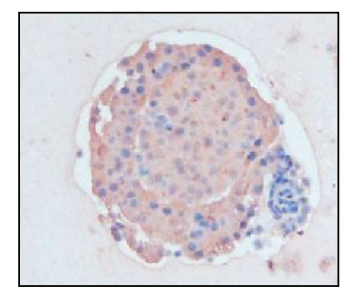

$\mathrm{Cl}+\mathrm{EPO}$

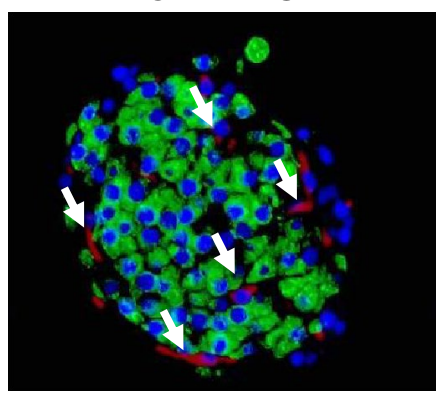

e

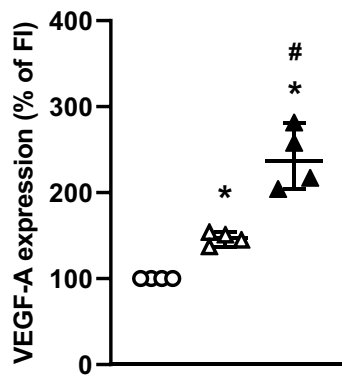

$\mathrm{Cl}+\mathrm{EPO}$

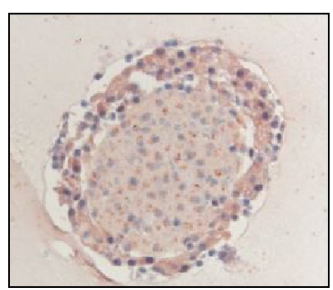

Fig. 2 Effects of EPO cultivation on cellular composition and gene expression of isolated islets. a Representative immunofluorescence stainings of insulin/CD31 within freshly isolated islets (FI), vehiclecultivated (CI+vehicle) and EPO-cultivated islets (CI+EPO). Cell nuclei are stained with Hoechst 33342 (blue). Scale bar: $25 \mu \mathrm{m}$. b and c Insulin-positive cells $\mathbf{b}$ and CD31-positive cells $\mathbf{c}$ of FI, CI+ vehicle and CI +EPO in \% of all islet cells ( $n=9$ each). Data are shown as scatter blots with median and $95 \%$ confidence interval. $* P<0.05$ vs. FI, ${ }^{\#} P<0.05$ vs. $\mathrm{CI}+$ vehicle. $\mathbf{d}$ and $\mathbf{e}$ Gene expression of insulin $\mathbf{d}$ and VEGF-A e of FI, CI + vehicle and CI+EPO ( $n=4$ each). FI were set $100 \%$. Data are shown as scatter blots with median and 95\% confidence interval. ${ }^{*} P<0.05$ vs. FI, ${ }^{\#} P<0.05$ vs. $\mathrm{CI}+$ vehicle. f Immunohistochemical stainings of EPOR in pancreatic tissue, FI, $\mathrm{CI}+$ vehicle and $\mathrm{CI}+\mathrm{EPO}$. Note: EPOR is expressed in islet cells. Scale bar: $45 \mu \mathrm{m}$ 
a

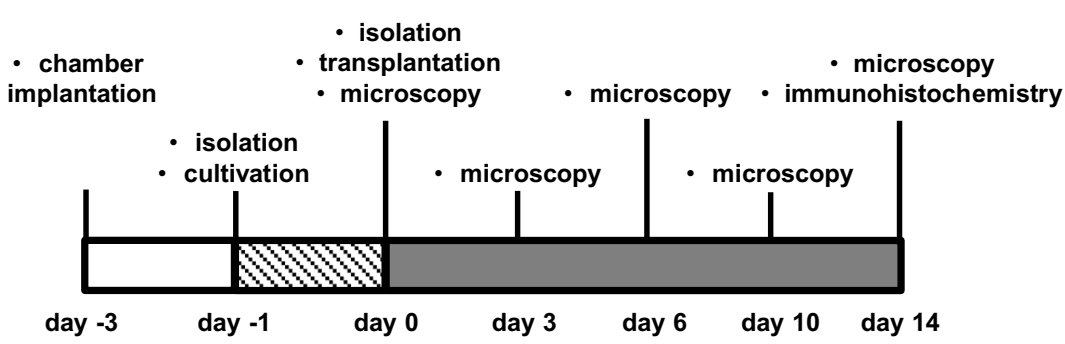

b

- $\mathrm{Fl}$

$\Delta \mathrm{Cl}+$ vehicle

$\Delta \mathrm{Cl}+\mathrm{EPO}$
C

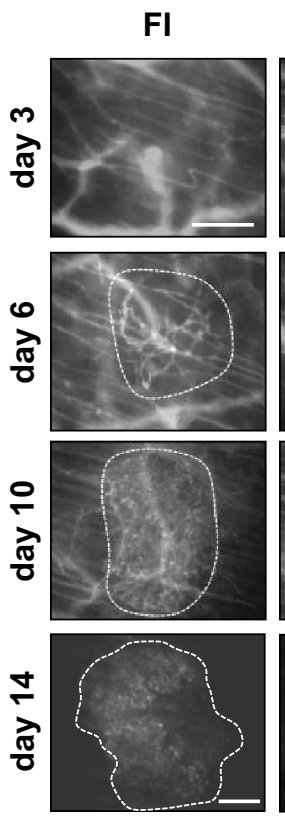

$\mathrm{Cl}+\mathrm{EPO}$
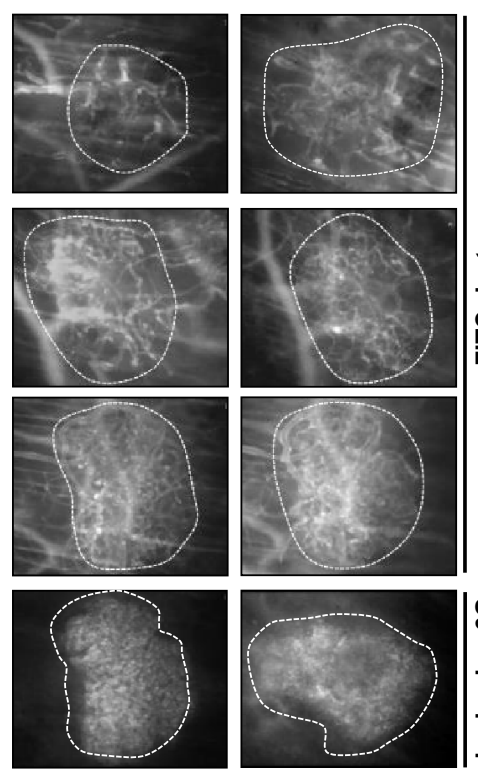

d

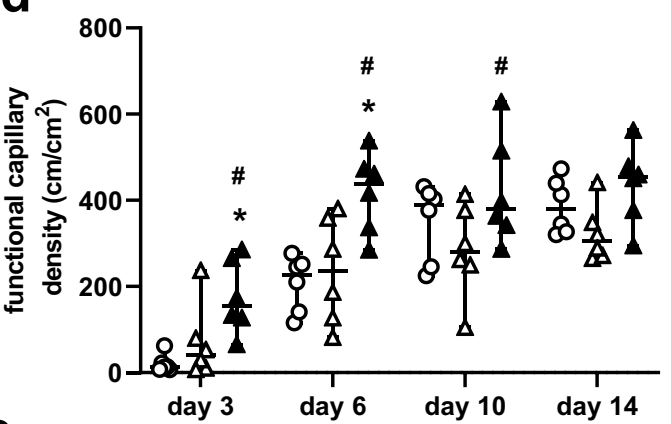

e

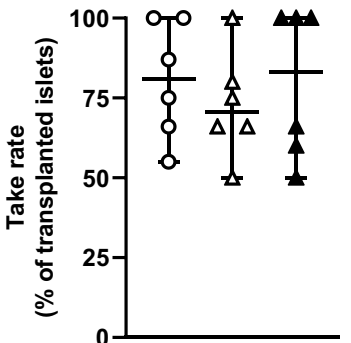

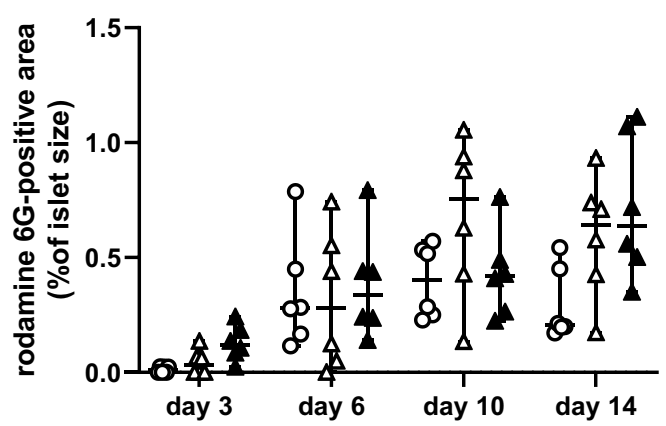

g

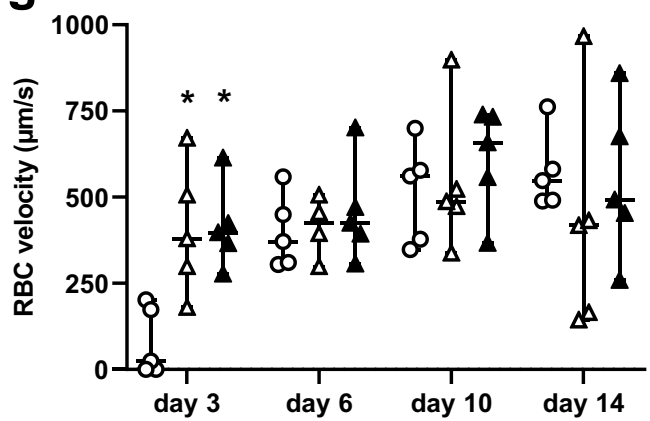

Effect of EPO cultivation on the cellular composition and gene expression of isolated islets

To investigate the effect of EPO on the cellular composition of isolated islets, we analyzed the number of insulin-producing cells and the number of CD31-positive cells by means of immunohistochemistry (Fig. 2a). Our quantitative analysis could not detect any differences in the number of insulin-positive cells in CI+EPO when compared to $\mathrm{CI}+$ vehicle and FI (Fig. 2b). However, a significantly 
4Fig. 3 Effect of EPO cultivation on revascularization of transplanted islets. a Experimental protocol of islet transplantation: On day -3 , dorsal skinfold chambers were implanted onto recipient mice. On day -1 , islets were isolated and cultivated for $24 \mathrm{~h}$ in the presence of vehicle $(\mathrm{CI}+$ vehicle $)$ or EPO $(\mathrm{CI}+\mathrm{EPO})$. On day 0, islets were isolated (FI) and FI, CI+ vehicle and CI+EPO were transplanted onto the striated muscle of dorsal skinfold chambers. Subsequently, the grafts were analyzed by intravital fluorescence microscopy on days $0,3,6$, 10 and 14. At the end of the experiments, the grafts were harvested for immunohistochemical analyses. b Take rate (\%) of FI, CI+ vehicle and $\mathrm{CI}+\mathrm{EPO}$ on day 14 after transplantation into the dorsal skinfold chamber of $\mathrm{FVB} / \mathrm{N}$ mice ( $n=6$ per group). Data are shown as scatter blots with median and $95 \%$ confidence interval. c Intravital fluorescence microscopic images of islets (marked by dotted lines) on days 3, 6, 10 and 14 after transplantation into dorsal skinfold chambers of FVB/N mice. The plasma marker FITC-dextran was used for the visualization of microvessels in blue light epi-illumination. Rhodamine $6 \mathrm{G}$ was injected to visualize the endocrine revascularization. Scale bar: $200 \mu \mathrm{m}$. d and e Functional capillary density $\left(\mathrm{cm} / \mathrm{cm}^{2}\right)$ d and rhodamine $6 \mathrm{G}$ positive area (\% of islet size) e of FI, CI+vehicle and $\mathrm{CI}+\mathrm{EPO}$ on days 3, 6, 10 and 14 after transplantation into the dorsal skinfold chambers of FVB/N mice ( $n=6$ per group). Data are shown as scatter blots with median and $95 \%$ confidence interval. *P $\mathbf{P} 0.05$ vs.FI; ${ }^{\#} P<0.05$ vs. CI + vehicle. $\mathbf{f}$ and $\mathbf{g}$ Diameter $(\mu \mathrm{m}) \mathbf{f}$ and $\mathrm{RBC}$ velocity $(\mu \mathrm{m} / \mathrm{s}) \mathrm{g}$ of FI, CI + vehicle and CI+vehicle on days 3, 6, 10 and 14 after transplantation into the dorsal skinfold chambers of $\mathrm{FVB} / \mathrm{N}$ mice ( $n=5$ per group). Data are shown as scatter blots with median and $95 \%$ confidence interval. $* \mathbf{P}<0.05$ vs.FI

lower fraction of CD31-positive cells was detected in $\mathrm{CI}+$ vehicle when compared to FI (Fig. 2a and c). In contrast, EPO exposure was capable of preventing the cultivation-induced reduction of CD31-positive cells (Fig. 2c).

Next, we examined the gene expression of insulin and VEGF-A by means of qRT-PCR. We found that the cultivation of islets reduces the insulin gene expression when compared to FI (Fig. 2d). Of note, this effect was completely abolished by the cultivation of the islets in the presence of EPO (Fig. 2d). The $24 \mathrm{~h}$ cultivation of islets increased VEGF-A gene expression compared to FI (Fig. 2e). This increase was further enhanced by EPO cultivation (Fig. 2e).

To exclude that the positive effects of EPO are mediated by an altered expression of EPOR after isolation or cultivation, we additionally analyzed the expression of this receptor in pancreatic tissue, FI, CI + vehicle and CI+EPO (Fig. 2f). The immunohistochemical analyses revealed that the expression of EPOR is neither affected by the isolation procedure nor by the cultivation.

\section{Effect of EPO cultivation on the revascularization of transplanted islets}

FI islets, $\mathrm{CI}+$ vehicle and $\mathrm{CI}+\mathrm{EPO}$ were transplanted onto the striated muscle tissue of dorsal skinfold chambers of recipient mice. The vascularization of the grafts was examined by means of intravital fluorescence microscopy on days $0,3,6,10$ and 14 (Fig. 3a). We found that cultivation of islets in the presence of EPO did not improve the take rate of the grafts, i.e., the fraction of engrafted islets on day 14 in relation to the total number of transplanted islets on day 0 (Fig. 3b). Repetitive intravital microscopy showed an increasing functional capillary density in the transplants of all groups throughout the entire observation period (Fig. 3c and d). Interestingly, we found a higher functional capillary density in particular on days 3 and 6 in CI + EPO animals when compared to $\mathrm{CI}+$ vehicle and FI controls. This clearly demonstrates that the cultivation of islets with EPO accelerates their revascularization.

Rhodamine $6 \mathrm{G}$ represents a marker for blood perfused endocrine tissue, because this fluorescent dye crosses the fenestrated endothelial lining and accumulates in the endocrine cells [20]. As expected, we measured an increased rhodamine 6G-positive area within all groups throughout the entire 14-day observation (Fig. 3c and e). On day 14, rhodamine $6 \mathrm{G}$ staining was higher in $\mathrm{CI}+\mathrm{EPO}$ when compared to FI, however, this effect did not prove to be statistically significant (Fig. 3e). The measurement of additional microhemodynamic parameters showed that cultivation of islets with EPO did not significantly affect the intra-islet vessel diameter (Fig. 3f), whereas the cultivation procedure of islets itself had a positive effect on the RBC velocity during the initial period of transplantation on day 3 (Fig. 3g).

Finally, we analyzed the number of intra-islet blood vessels by means of immunohistochemistry on day 14 (Fig. 4a). We did not observe any differences in the number of insulinpositive cells and CD31-positive cells between FI, CI + vehicle and CI+EPO (Fig. 4b and c). Of interest, we detected a significantly increased number of GFP/CD31-positive cells in $\mathrm{CI}+\mathrm{EPO}$ when compared to $\mathrm{CI}+$ vehicle. This indicates that EPO may protect intra-islet endothelial cells from stress-induced cell death during cultivation (Fig. 4a and d).

\section{Discussion}

We have recently shown that 5-day pretreatment of recipient mice with EPO significantly accelerates the revascularization of transplanted islets [10]. However, in clinical practice there is little time between receiving the appropriate donor pancreas and the transplantation itself. Hence, pretreatment of patients with EPO is hard to realize in clinical practice [10]. In the present study, we analyzed whether cultivation of isolated islets with EPO prior to transplantation improves their posttransplant revascularization. Our results demonstrate that cultivation of islets with EPO does not affect their viability and cellular composition, and does not induce ROS formation. However, EPO cultivation preserves old blood vessels within the grafts during the initial phase after transplantation.

It is controversially discussed whether the cultivation of islets prior to transplantation leads to similar results 

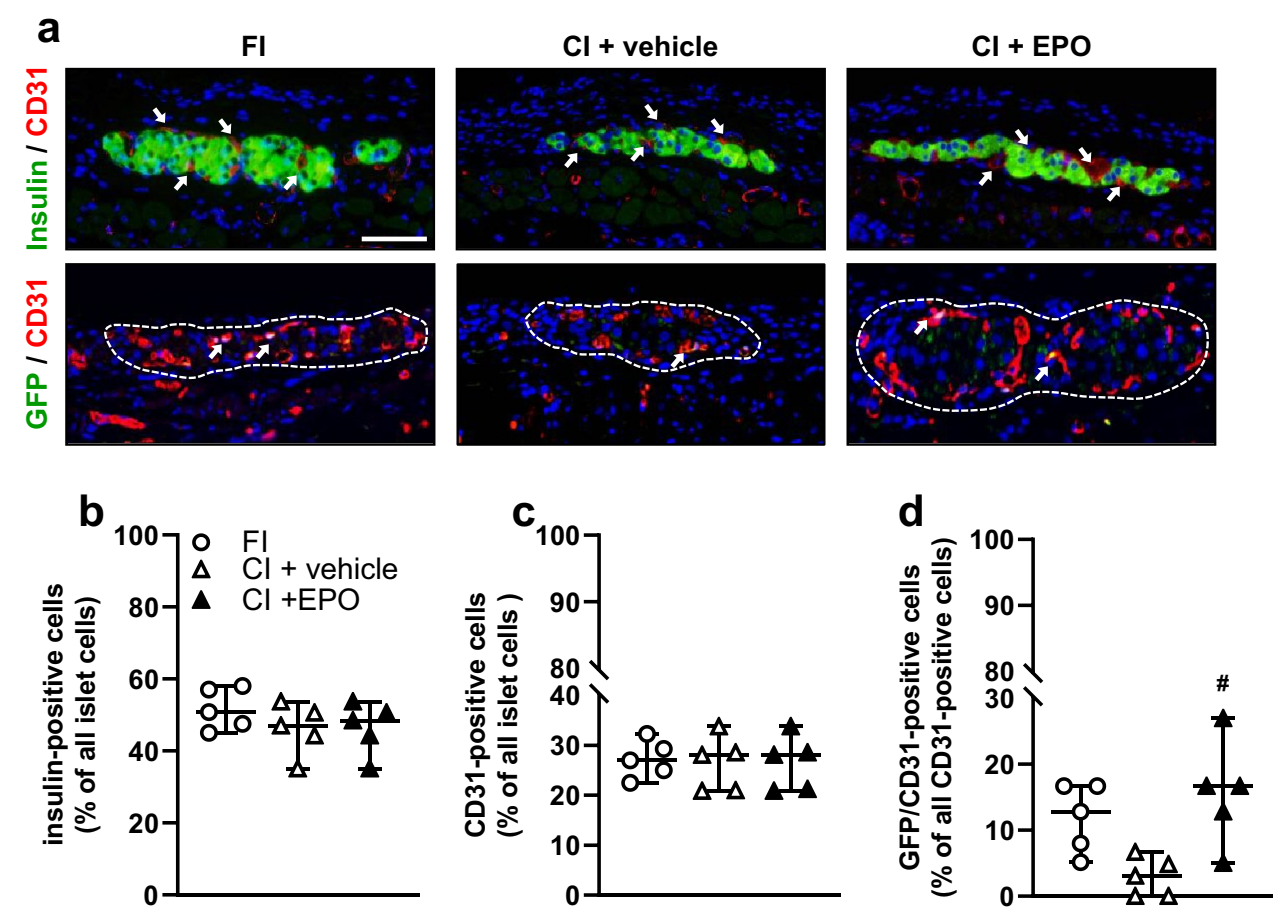

Fig. 4 Immunohistochemical analysis of transplanted islets. a Immunofluorescence staining of insulin / CD31 (arrows $=$ CD31-positive cells) and GFP / CD31 (arrows $=$ GFP/CD31-positive cells) within $\mathrm{FI}, \mathrm{CI}+$ vehicle and $\mathrm{CI}+\mathrm{EPO}$ on day 14 after transplantation into the dorsal skinfold chamber of FVB/N mice. Scale bar: $25 \mu \mathrm{m}$. b and c Quantitative analysis of insulin- $\mathbf{b}$ and CD31-positive cells $\mathbf{c}$ within FI, $\mathrm{CI}+$ vehicle and $\mathrm{CI}+\mathrm{EPO}$ on day 14 after transplantation into the dorsal skinfold chambers of FVB/N mice (\% of all islet cells; $n=5$ per group). Data are shown as scatter blots with median and $95 \%$ confidence interval. d Quantitative analysis of GFP/CD31-positive cells within transplanted islets on day 14 after transplantation into the dorsal skinfold chambers of FVB/N mice (in \% of all CD31-positive cells) ( $n=5$ per group). Data are shown as scatter blots with median and $95 \%$ confidence interval. ${ }^{\#} P<0.05$ vs. $\mathrm{CI}+$ vehicle compared to FI [21, 22]. Nonetheless, the cultivation has several advantages. For instance, it allows to improve viability by the cultivation of islets in the presence of antiapoptotic compounds and allows the shipping of the islets to remote clinical transplant centers [23, 24]. Moreover, a brief cultivation for $24 \mathrm{~h}$ to $48 \mathrm{~h}$ prior to transplantation may allow recovery from cellular stress, induced by the islet isolation procedure and may allow the depletion of passenger leukocytes [25, 26].

EPO exerts anti-apoptotic and anti-inflammatory effects [27-29]. On the other hand, Zhao et al. [30] reported that the binding of EPO to EPOR is also capable of inducing ROS formation via activation of JAK2-STAT5 signaling. To exclude that subsequent effects are influenced by ROSmediated changes in cell viability, we have first analyzed the effect of EPO cultivation on ROS formation and islet viability. In fact, EPO neither induced cell death nor affected the formation of ROS.

Further we studied the cellular composition of cultured and freshly isolated islets. We did not detect any differences in the fraction of insulin-positive cells between the groups. However, we found a significantly reduced insulin gene expression in $\mathrm{CI}+$ vehicle when compared to FI. Of note, this reduction of tissue gene expression was not detectable after cultivation of islets with EPO. This may be explained by the fact that pancreatic $\beta$-cells are positive for EPOR [7, 31] and EPO signaling activates JAK2-STAT5 pathways [32]. Because knockout of STAT5 dramatically reduces insulin secretion [33], EPO may increase insulin expression via STAT5 activation.

The analysis of the vascular fraction in FI, CI+ vehicle and $\mathrm{CI}+\mathrm{EPO}$ revealed that the cultivation procedure itself reduces the number of endothelial cells. This is in line with previous studies reporting a progressive loss of endothelial cells during islet cultivation $[34,35]$. Of interest, EPO is capable of counteracting this endothelial cell loss during cultivation. Trincavelli et al. [36] investigated the effects of different erythropoietin derivatives such as EPO $\alpha$, darbepoetin (DarbEPO) and continuous EPOR activator (CERA) on EPOR desensitization and signaling resensitization. They found that EPO increases endothelial cell viability through a mechanism involving STAT5 activation [36]. Therefore, it is tempting to speculate that EPO protects intra-islet endothelial cells against cultivation-induced cell death.

To investigate whether EPO cultivation improves the revascularization of transplanted islets, we implanted dorsal 
skinfold chambers onto recipient mice and subsequently transplanted FI, CI + vehicle and CI + EPO onto the striated skin muscle tissue. We detected an increased functional capillary density until day 10 after transplantation in all groups. Of note, this effect was most pronounced in the group of $\mathrm{CI}+\mathrm{EPO}$. It is well known that pro-angiogenic factors such as VEGF-A stimulate the formation of new blood vessels $[37,38]$. VEGF-A is mainly produced by $\alpha$ - and $\beta$-cells [39] and regulates angiogenesis by inducing endothelial cell proliferation, migration and survival [40]. Choi et al. [9] detected increased VEGF mRNA levels in EPO-treated $\mathrm{db} / \mathrm{db}$ mice when compared to controls. We herein detected a significantly increased VEGF-A expression in EPO-cultivated islets when compared to both controls. Therefore, we assume that the accelerated revascularization in the EPOcultivated group is triggered by VEGF-A.

We did not detect significant differences in the take rate, blood vessel fenestration and vessel diameter between the three experimental groups. However, RBC velocity of $\mathrm{CI}+$ vehicle and $\mathrm{CI}+\mathrm{EPO}$ was significantly increased on day 3 when compared to FI. This may support the revascularization process during the initial phase after transplantation by an increased nutrient and oxygen supply.

Finally, we assessed the cellular composition of the grafts 14 days after transplantation. As expected, we observed no differences in the ratio of insulin- and CD31-positive islet cells between the study groups. To analyze the origin of intra-islet endothelial cells, we used islets from Tie2/GFPpositive donor mice. Our data show that donor islet endothelial cells contributed to $\sim 10 \%$ to the islet vasculature in the group of FI. This is in line with previous studies demonstrating that the revascularization of transplanted islets is mainly caused by recipient endothelial cells of host origin [41-43]. In CI, we measured a decreased number of intraislet endothelial cells. Of note, the cultivation of islets with EPO was capable of preventing this endothelial cell loss. This may be explained by our in vitro observation, which shows that cultivation of islets in the presence of EPO results in a higher number of intra-islet endothelial cells. Hence, the increased number of recipient microvessels in EPO-pretreated islets may contribute to the accelerated graft revascularization through inosculation with the host vasculature.

Clinical islet transplantation is usually performed by an intraportal infusion of islets [44]. Recently, Chen et al. [45] visualized for the first time the revascularization of intraportally transplanted islets in diabetic mice by panoramic and in-depth imaging of the graft microstructure. This approach revealed that although the transplanted islets have access to nutrients and oxygen immediately after transplantation, an accelerated graft-hepatic integration by blood microvessels plays an essential role for long-term graft survival. In the present study, we did not transplant islets intraportally nor did we use diabetic mice as recipients. However, the herein observed beneficial effects of EPO exposure of isolated islets may have impact on clinical islet transplantation by improving the revascularization of intraportally transplanted islets [46].

Taken together, we herein demonstrate that cultivation of islets with EPO significantly accelerates the revascularization of transplanted islets during the initial days after transplantation. This is most probably due to the enhanced gene expression of insulin and VEGF-A driven the inosculation. Besides EPO, darbepoietin (DPO)- $\alpha$, a long lasting analogue of EPO has also been reported to stimulate angiogenesis in vitro and in vivo [47, 48]. Moreover, we have shown that treatment of mice with DPO after islet transplantation increases the blood volume flow in the grafts [49]. Therefore, cultivation of islets with EPO or even DPO prior to transplantation may represent a successful strategy to improve the outcome of clinical islet transplantation.

Acknowledgements We are grateful for the excellent technical assistance of Caroline Bickelmann.

Funding Open Access funding enabled and organized by Projekt DEAL.

\section{Declarations}

Conflict of interest The authors declare no conflicts of interest.

Ethical approval All experiments were performed according to the German legislation on action of animals and the National Institutes of Health (NIH) Guide for the Care and Use of Laboratory Animals (Institute of Laboratory Animal Resources, National Research Council, Washington DC, USA). The local governmental animal protection committee approved them.

Informed consent For this type of study informed consent is not required.

Open Access This article is licensed under a Creative Commons Attribution 4.0 International License, which permits use, sharing, adaptation, distribution and reproduction in any medium or format, as long as you give appropriate credit to the original author(s) and the source, provide a link to the Creative Commons licence, and indicate if changes were made. The images or other third party material in this article are included in the article's Creative Commons licence, unless indicated otherwise in a credit line to the material. If material is not included in the article's Creative Commons licence and your intended use is not permitted by statutory regulation or exceeds the permitted use, you will need to obtain permission directly from the copyright holder. To view a copy of this licence, visit http://creativecommons.org/licenses/by/4.0/.

\section{References}

1. Rickels MR, Robertson RP (2019) Pancreatic islet transplantation in humans: recent progress and future directions. Endocr Rev 40(2):631-668. https://doi.org/10.1210/er.2018-00154 
2. Pepper AR, Gala-Lopez B, Ziff O, Shapiro AM (2013) Revascularization of transplanted pancreatic islets and role of the transplantation site. Clin Dev Immunol 2013:352315. https://doi.org/ $10.1155 / 2013 / 352315$

3. Karschnia P, Scheuer C, Hess A, Spater T, Menger MD, Laschke MW (2018) Erythropoietin promotes network formation of transplanted adipose tissue-derived microvascular fragments. Eur Cell Mater 35:268-280. https://doi.org/10.22203/eCM.v035a19

4. Watanabe D, Suzuma K, Matsui S et al (2005) Erythropoietin as a retinal angiogenic factor in proliferative diabetic retinopathy. N Engl J Med 353(8):782-792. https://doi.org/10.1056/NEJMo a041773

5. Li Y, Lu Z, Keogh CL, Yu SP, Wei L (2007) Erythropoietininduced neurovascular protection, angiogenesis, and cerebral blood flow restoration after focal ischemia in mice. J Cereb Blood Flow Metab 27(5):1043-1054. https://doi.org/10.1038/sj.jcbfm. 9600417

6. Alvarez Arroyo MV, Castilla MA, Gonzalez Pacheco FR et al (1998) Role of vascular endothelial growth factor on erythropoietin-related endothelial cell proliferation. J Am Soc Nephrol 9(11):1998-2004

7. Fenjves ES, Ochoa MS, Cabrera O et al (2003) Human, nonhuman primate, and rat pancreatic islets express erythropoietin receptors. Transplantation 75(8):1356-1360. https://doi.org/10.1097/01.TP. 0000062862.88375.BD

8. Chen LN, Sun Q, Liu SQ et al (2015) Erythropoietin improves glucose metabolism and pancreatic beta-cell damage in experimental diabetic rats. Mol Med Rep 12(4):5391-5398. https://doi. org/10.3892/mmr.2015.4006

9. Choi D, Schroer SA, Lu SY et al (2010) Erythropoietin protects against diabetes through direct effects on pancreatic beta cells. J Exp Med 207(13):2831-2842. https://doi.org/10.1084/jem.20100 665

10. Menger MM, Nalbach L, Roma LP et al (2019) Erythropoietin accelerates the revascularization of transplanted pancreatic islets. Br J Pharmacol. https://doi.org/10.1111/bph.14925

11. Motoike T, Loughna S, Perens E et al (2000) Universal GFP reporter for the study of vascular development. Genesis 28(2):75-81

12. Fujikawa Y, Roma LP, Sobotta MC et al (2016) Mouse redox histology using genetically encoded probes. Sci Signal 9(419):rs1. https://doi.org/10.1126/scisignal.aad3895

13. Beger C, Cirulli V, Vajkoczy P, Halban PA, Menger MD (1998) Vascularization of purified pancreatic islet-like cell aggregates (pseudoislets) after syngeneic transplantation. Diabetes 47(4):559-565

14. Laschke MW, Vollmar B, Menger MD (2011) The dorsal skinfold chamber: window into the dynamic interaction of biomaterials with their surrounding host tissue. Eur Cell Mater 22:147-164

15. Vajkoczy P, Menger MD, Simpson E, Messmer K (1995) Angiogenesis and vascularization of murine pancreatic islet isografts. Transplantation 60(2):123-127

16. Menger MD, Vajkoczy P, Leiderer R, Jager S, Messmer K (1992) Influence of experimental hyperglycemia on microvascular blood perfusion of pancreatic islet isografts. J Clin Invest 90(4):13611369. https://doi.org/10.1172/JCI116002

17. Ampofo E, Rudzitis-Auth J, Dahmke IN, Roessler OG, Thiel G, Montenarh M, Menger MD, Laschke MW (2015) Inhibition of protein kinase CK2 suppresses tumor necrosis factor (TNF)-alphainduced leukocyte-endothelial cell interaction. Biochim Biophys Acta 1852 (10): 2123-2136. doi:S0925-4439(15)00205-7 [pii] https://doi.org/10.1016/j.bbadis.2015.07.013

18. Giuliani M, Moritz W, Bodmer E et al (2005) Central necrosis in isolated hypoxic human pancreatic islets: evidence for postisolation ischemia. Cell Transplant 14(1):67-76. https://doi.org/10. 3727/000000005783983287
19. Ma Z, Moruzzi N, Catrina SB, Grill V, Bjorklund A (2014) Hyperoxia inhibits glucose-induced insulin secretion and mitochondrial metabolism in rat pancreatic islets. Biochem Biophys Res Commun 443(1):223-228. https://doi.org/10.1016/j.bbrc.2013.11.088

20. Diez JA, Arrojo EDR, Zheng X et al (2017) Pancreatic islet blood flow dynamics in primates. Cell Rep 20(6):1490-1501. https://doi. org/10.1016/j.celrep.2017.07.039

21. Froud T, Ricordi C, Baidal DA et al (2005) Islet transplantation in type 1 diabetes mellitus using cultured islets and steroid-free immunosuppression: Miami experience. Am J Transplant Off J Am Soc Transplant Am Soc Transplant Surg 5(8):2037-2046. https://doi.org/10.1111/j.1600-6143.2005.00957.x

22. Noguchi H, Miyagi-Shiohira C, Kurima K et al (2015) Islet culture/preservation before islet transplantation. Cell Med 8(1-2):2529. https://doi.org/10.3727/215517915X689047

23. Kempf MC, Andres A, Morel P et al (2005) Logistics and transplant coordination activity in the GRAGIL Swiss-French multicenter network of islet transplantation. Transplantation 79(9):1200-1205. https://doi.org/10.1097/01.tp.0000161224. 67535.41

24. Goss JA, Goodpastor SE, Brunicardi FC et al (2004) Development of a human pancreatic islet-transplant program through a collaborative relationship with a remote islet-isolation center. Transplantation 77(3):462-466. https://doi.org/10.1097/01.TP. 0000100397.86756.A3

25. Ihm SH, Matsumoto I, Zhang HJ, Ansite JD, Hering BJ (2009) Effect of short-term culture on functional and stress-related parameters in isolated human islets. Transplant Int : Off J Euro Soc Organ Transplant 22(2):207-216. https://doi.org/10.1111/j. 1432-2277.2008.00769.x

26. Abdelli S, Ansite J, Roduit R et al (2004) Intracellular stress signaling pathways activated during human islet preparation and following acute cytokine exposure. Diabetes 53(11):2815-2823. https://doi.org/10.2337/diabetes.53.11.2815

27. Heikal L, Ghezzi P, Mengozzi M, Stelmaszczuk B, Feelisch M, Ferns GA (2016) Erythropoietin and a nonerythropoietic peptide analog promote aortic endothelial cell repair under hypoxic conditions: role of nitric oxide. Hypoxia 4:121-133. https://doi. org/10.2147/HP.S104377

28. Harder Y, Amon M, Schramm R et al (2009) Erythropoietin reduces necrosis in critically ischemic myocutaneous tissue by protecting nutritive perfusion in a dose-dependent manner. Surgery 145(4):372-383. https://doi.org/10.1016/j.surg.2008.12. 001

29. Grimm C, Wenzel A, Groszer M et al (2002) HIF-1-induced erythropoietin in the hypoxic retina protects against light-induced retinal degeneration. Nat Med 8(7):718-724. https://doi.org/10.1038/ $\mathrm{nm} 723$

30. Zhao B, Mei Y, Yang J, Ji P (2016) Erythropoietin-regulated oxidative stress negatively affects enucleation during terminal erythropoiesis. Exp Hematol 44(10):975-981. https://doi.org/10.1016/j. exphem.2016.06.249

31. Fenjves ES, Ochoa MS, Gay-Rabinstein C et al (2004) Adenoviral gene transfer of erythropoietin confers cytoprotection to isolated pancreatic islets. Transplantation 77(1):13-18. https://doi.org/10. 1097/01.TP.0000110422.27977.26

32. Constantinescu SN, Ghaffari S, Lodish HF (1999) The erythropoietin receptor: structure, activation and intracellular signal transduction. Trends Endocrinol Metab 10(1):18-23. https://doi. org/10.1016/s1043-2760(98)00101-5

33. Jackerott M, Moldrup A, Thams P et al (2006) STAT5 activity in pancreatic beta-cells influences the severity of diabetes in animal models of type 1 and 2 diabetes. Diabetes 55(10):2705-2712. https://doi.org/10.2337/db06-0244

34. Mendola JF, Goity C, Fernandez-Alvarez J et al (1994) Immunocytochemical study of pancreatic islet revascularization in islet 
isograft Effect of hyperglycemia of the recipient and of in vitro culture of islets. Transplantation 57(5):725-730. https://doi.org/ 10.1097/00007890-199403150-00015

35. Parr EL, Bowen KM, Lafferty KJ (1980) Cellular changes in cultured mouse thyroid glands and islets of Langerhans. Transplantation 30(2):135-141. https://doi.org/10.1097/00007890-19800 8000-00012

36. Trincavelli ML, Da Pozzo E, Ciampi O et al (2013) Regulation of erythropoietin receptor activity in endothelial cells by different erythropoietin (EPO) derivatives: an in vitro study. Int J Mol Sci 14(2):2258-2281. https://doi.org/10.3390/ijms14022258

37. Lammert E, Gu G, McLaughlin M et al (2003) Role of VEGF$\mathrm{A}$ in vascularization of pancreatic islets. Current Biol : $\mathrm{CB}$ 13(12):1070-1074. https://doi.org/10.1016/s0960-9822(03) 00378-6

38. Watada H (2010) Role of VEGF-A in pancreatic beta cells. Endocr J 57(3):185-191. https://doi.org/10.1507/endocrj.k09e-035

39. Brissova M, Shostak A, Shiota M et al (2006) Pancreatic islet production of vascular endothelial growth factor-a is essential for islet vascularization, revascularization, and function. Diabetes 55(11):2974-2985. https://doi.org/10.2337/db06-0690

40. Shibuya M (2011) Vascular endothelial growth factor (VEGF) and its receptor (VEGFR) signaling in angiogenesis: a crucial target for anti- and pro-angiogenic therapies. Genes Cancer 2(12):10971105. https://doi.org/10.1177/1947601911423031

41. Nyqvist D, Kohler M, Wahlstedt H, Berggren PO (2005) Donor islet endothelial cells participate in formation of functional vessels within pancreatic islet grafts. Diabetes 54(8):2287-2293

42. Henriksnas J, Lau J, Zang G, Berggren PO, Kohler M, Carlsson PO (2012) Markedly decreased blood perfusion of pancreatic islets transplanted intraportally into the liver: disruption of islet integrity necessary for islet revascularization. Diabetes 61(3):665673. https://doi.org/10.2337/db10-0895

43. Vajkoczy P, Olofsson AM, Lehr HA et al (1995) Histogenesis and ultrastructure of pancreatic islet graft microvasculature Evidence for graft revascularization by endothelial cells of host origin. Am J Pathol 146(6):1397-1405

44. Shapiro AM, Pokrywczynska M, Ricordi C (2017) Clinical pancreatic islet transplantation. Nat Rev Endocrinol 13(5):268-277. https://doi.org/10.1038/nrendo.2016.178

45. Chen CC, Peng SJ, Wu PY et al (2021) Heterogeneity and neurovascular integration of intraportally transplanted islets revealed by 3-D mouse liver histology. Am J Physiol Endocrinol Metab. https://doi.org/10.1152/ajpendo.00605.2020

46. Barshes NR, Wyllie S, Goss JA (2005) Inflammation-mediated dysfunction and apoptosis in pancreatic islet transplantation: implications for intrahepatic grafts. J Leukoc Biol 77(5):587-597. https://doi.org/10.1189/jlb.1104649

47. Broberg AM, Grinnemo KH, Genead R et al (2008) Erythropoietin has an antiapoptotic effect after myocardial infarction and stimulates in vitro aortic ring sprouting. Biochem Biophys Res Commun 371(1):75-78. https://doi.org/10.1016/j.bbrc.2008.04. 025

48. Rupertus K, Senger S, Menger MD, Schilling MK, Kollmar O (2012) Darbepoetin-alpha promotes neovascularization and cell proliferation in established colorectal liver metastases. J Surg Res 176(2):517-523. https://doi.org/10.1016/j.jss.2011.09.062

49. Menger MM, Nalbach L, Roma LP et al (2020) Erythropoietin accelerates the revascularization of transplanted pancreatic islets. Br J Pharmacol 177(7):1651-1665. https://doi.org/10.1111/bph. 14925

Publisher's Note Springer Nature remains neutral with regard to jurisdictional claims in published maps and institutional affiliations. 